\title{
尾瀬国立公園尾瀬ヶ原の山ノ鼻〜牛首分岐の木道における混雑感の改善策について
}

\section{A study of appropriate plan for crowding perception on a wooden path between Yamanohana and Ushikubi-Bunki in Ozegahara, Oze National Park}

一場 博幸*

\section{Hiroyuki ICHIBA}

\begin{abstract}
In national parks, it is one of the indispensable requirements to avoid the crowding perception by the visitors to enable them to have more valuable experiences. Annually, it comes to be highly crowded in Ozegahara, Oze National Park, during a specific period such as Mizubasho (Asian skunk cabbages) blossom season. However, there has been no work done which totalizes the existing opinions concerned with the crowding perception of Ozegahara and examines the ways to improve the condition. Thus, this study takes up the wooden path between Yamanohana and Ushikubi-Bunki as the study area because it is where the crowding peaks in Ozegahara, then rearranges the existing studies of the crowding perception, and clarifies the actual perception of congestion by using the data of visitors' number. Next, it indicates that an important measure for its improvement is to set "the maximum visitor's number per day" of approximately 3200 visitors as the baseline, and to adjust the number of visitors coming into Ozegahara from Hatomachi-Toge to avoid exceeding the baseline. Further, it discusses the trial plan for the improvement of crowding perception and the problems of its appliance by using two concrete frameworks: measures of instruction and regulation.
\end{abstract}

Keywords : National Park, Oze, Ozegahara, wooden path, crowding perception キーワード：国立公園, 尾瀬, 尾瀬ヶ原, 木道, 混雑感

\section{1.はじめに}

多くの国民は，都市での日常生活から一時的に離脱し，自然と のふれあいを求めて自然公園を利用し，都会に見られるような雑 踏風景を求めて来訪するわけではない。つまり，自然公園におい ては, 混雑感をもたらさないようにすることが必須要件の一つと してあげられる。尾瀬国立公園の中核区域は，国立公園の中で最 も価值の高い特別保護地区に指定されている。普段はほとんど混 雑しないが，例年ミズバショウやニッコウキスゲの開花期や紅葉 期の土日・祝日になると非常に混雑する（以下，これを特定混雑 日という)。特に尾瀬ヶ原の山ノ鼻〜牛首分岐では一時的にではあ るが，木道上に $300 \mathrm{~m}$ を超す長蛇の列が出現する。このような状 況になると木道上で立ち止まって，ゆっくり辺りの風景を眺める ことは許されず，行列の流れにあわせて，ひたすら“行進”しな ければならない（写真一 1$)$ 。また，木道に沿って点在する休爵テ ラスも人で埋めつくされ，休顋したいと思う所で休憩もできない。

こうした混雑の問題は, 既に 1960 年頃より発生しており ${ }^{1)}$, これまでに山小屋の完全予約・定員制の実施 (1992 年〜) などの 混雑対策が講じられてきたが，特に「特定混雑日」においては,

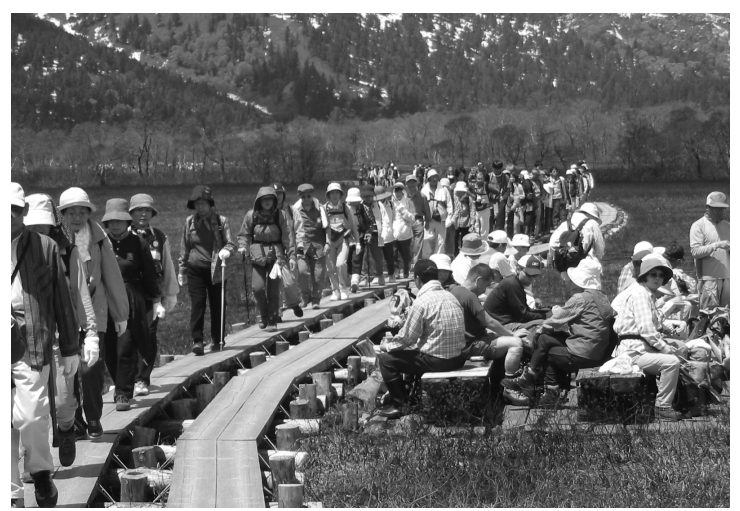

写真-1 混雑時の尾瀬ヶ原・上田代（6 月上旬）
まだ十分な効果が得られているとはいえない状況である。近年, 国内外の自然公園において混䧱対策を講じている公園管理システ ムについて見ると，次のとおりである。

米国では 1995 年に国立公園において自然資源および利用体験 の保全を同時に図る計画管理フレームとして VERP ${ }^{2)}$ (Visitor Experience and Resource Protection）が導入され，公園の望ま しい将来像のもとに管理の指標と水準を設定し，モニタリングに よる順応的管理が行われている。混雑対策についても，この中に 組み入れられており，例えば，アーチーズ国立公園では遊歩道の 出発点における自動車の駐車可能台数を制限し，間接的に混雑し ないように利用者数が調整されている ${ }^{3)}$ 。

一方，日本では 2002 年に自然公園法が改正され，国立・国定 公園の特別地域において自然環境の維持とその適正な利用を図る ために，利用者の行為や人数等を調整することができる「利用調 整地区制度」が創設された。これは，2006 年に吉野熊野国立公園 の西大台地区（大台ヶ原）において初めて適用され，1 日当たり の総利用者数の上限や 1 グループあたりの最大人数などが設定さ れた ${ }^{4)}$ 。これについて 7 割弱の利用者が満足と回答し，再訪の意 向を示しており，当制度への評価が概ね高いことが明らかになっ ている5）。また, 2011 年から知床国立公園の知床五湖においても 適用されることになり，1 グループあたりの最大人数などが計画 されている ${ }^{6)}$ 。両方とも順応的管理の方針に基づき，モニタリン グを行い，必要に応じて設定内容を変更することになっている。

こうした国内外の動向を見れば, 公園の生態系の保全とともに, 利用体験の質を保全しようとする流れになっていることがわかる。 尾瀬ヶ原においても同様に混雑の問題に対してさらに有効な対策 を講じて利用体験の質の保全に努めなければならないであろう。 尾瀬保護財団は，2000 年から 5 力年に渡って尾瀬ヶ原と尾瀬沼 における利用体験上の収容力に関寸る調査を行い，その目安を設 定した ${ }^{7)}$ 。また，その関係者らの手によって尾瀬ヶ原と尾瀬沼の 混雑感の改善につながる様々な知見が発表された ${ }^{8 ） 9 １ 10) 11 。 し か ~}$

*田園都市研究所 
し，これらはあくまでも基礎的な知見であり，これらを単に積み 上げても，その改善策にはならない。これらの知見を総合的に捉 え直し, 利用実態に見合った混雑感の改善策をまとめ, これを適 用し現状の改善を図らなければならない。

そこで，本論は，尾瀬ヶ原の山ノ鼻〜牛首分岐の木道における 利用集中による混雑感の問題を取り上げて，既往の混雑感に関す る知見と実際の利用データをもとにして, その実態を明らかにし， 混雑感の改善策の試案とその適用上の課題について整理した。

本論での検討対象について以下に整理しておく。(1)本論では特 定混雑日に尾瀬ヶ原の中で最も混雑する山ノ鼻〜牛首分岐の木道 に限定する (図一 1$)$ 。この区間は尾瀬ヶ原の中でも比較的に池塘 が多く分布し，個性的で美しい湿原空間である。他に鳩待峠〜山 ノ鼻の森林带内も非常に混雑する区間であるが，検討対象外にす る。(2)通常であれば「特定混雑日」になるが，雨天や台風等の天 候や熊の出没等の影響によって「特定混雑日」にならない場合も ある。本論ではそれについては考慮しない。(3)現在，尾瀬では 6 〜 割が日帰り利用であるが，尾瀬ヶ原内の山小屋への宿泊率や 連泊率が上がれば，山ノ鼻〜牛首分岐の木道の利用状況が変わる 可能性がある。しかし, 本論では現在の利用パターンを前提とし, それについては考慮しない。(4)混雑感をもたらす要因として空間 内の 1 グループの人数，グループ数もあげられるが，山ノ鼻〜牛 首分岐の木道では混雑すると利用者が数珠繫ぎ状態になるため,

本論では検討対象外にする。(5)混雑に対応して山ノ鼻〜牛首分岐 において休憩テラスの増設，湿原周囲の林縁部を利用した別ルー トの整備といった案も考えられる。しかし，2006 年に「尾瀬の保 護と利用のあり方検討委員会」が「尾瀬ビジョン」 ${ }^{12)}$ を発表し基 本方針として尾瀬の保護のために「現状をこえる利用のための施 設整備は，特別保護地区内では原則として行わない」ことを掲げ ている。したがって，本論では施設整備は検討対象外とした。

本論で使用する用語について以下に整理しておく。(1)「混雑感」 とは, ある空間内の利用密度に対する利用者の負の評価とする ${ }^{13)}$ 。 (2)「混杂隹感の許容限界」とは, 混雑は感じるものの不快には感じ ずに許容できる限界を示す。これは，愛甲ら（2000）が登山道や 野営地における「利用者数の許容限界」について，「不快に感じな いで許容できる限界を示す」 ${ }^{14)}$ とした表現とニュアンスが近いも のである。(3)「混雑感の改善」とは，ある空間内の利用密度を下 げて，利用者の負の評価を改善することである。

\section{2. 研究方法}

\section{（1）スタディ・エリアの利用環境上の位置づけ}

尾瀬ヶ原は, 図一2のように鳩待峠, 富士見峠 (富士見下経由), 御池（燧裏林道経由），見晴（大清水・沼山峠・尾瀬沼経由）の 4 つ入山口（出入口）がある。尾瀬ヶ原の利用者数（2009年度） は, 鳩待峠口において約 180,000 人，その以外の入山口からの利 用者数は約 20,000 人，合わせて約 200,000 人と推計される ${ }^{15)}$ 。 つまり，尾瀬ヶ原利用者の約 9 割は鳩待峠から入り，そのほとん どが山ノ鼻から牛首分岐方面の湿原内に流入するが，山ノ鼻から 牛首分岐までは, $2.2 \mathrm{~km}$ の木道が 1 ルトしかない。しかも，木 道上の混雑を回避できる休喤テラスは $300 ６ 00 \mathrm{~m}$ に 1 か所ずつ, 計 4 基しかない。このため，このルートに利用集中すれば必然的 に混雑する。木道上を往来する人たちはそれを回避することはで きず，前述したような混雑を受容しなければならない。

\section{(2) 既往研究データの抽出・整理}

これまでに尾瀬ケ原の混杂隹感に係わる学術論文が多数発表され ている。この中から特に山ノ鼻〜牛首分岐の木道の混雑感の改善 策に利用できる既往研究データを抽出し, 整理した。
（3）利用状況の計測方法
山ノ鼻の湿原口（図一2）をビデオ撮影し，後日，その録画を

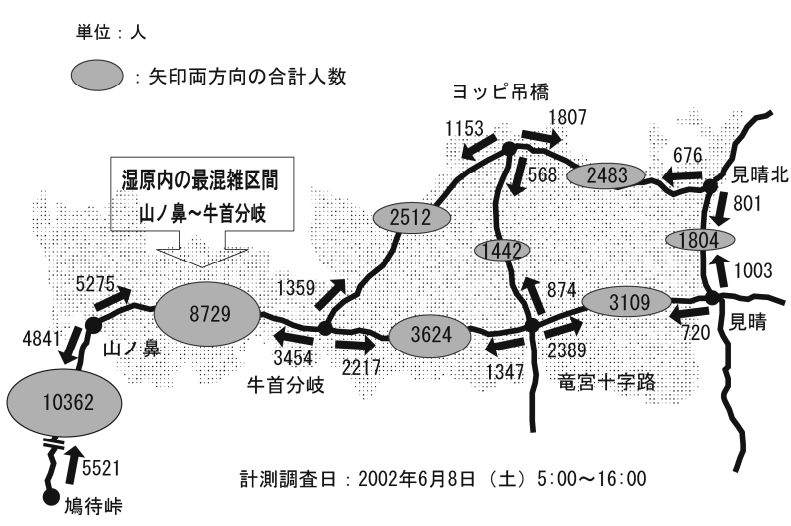

図-1 尾瀬ヶ原の区間別利用状況（最大混雑日の例） ${ }^{8)}$

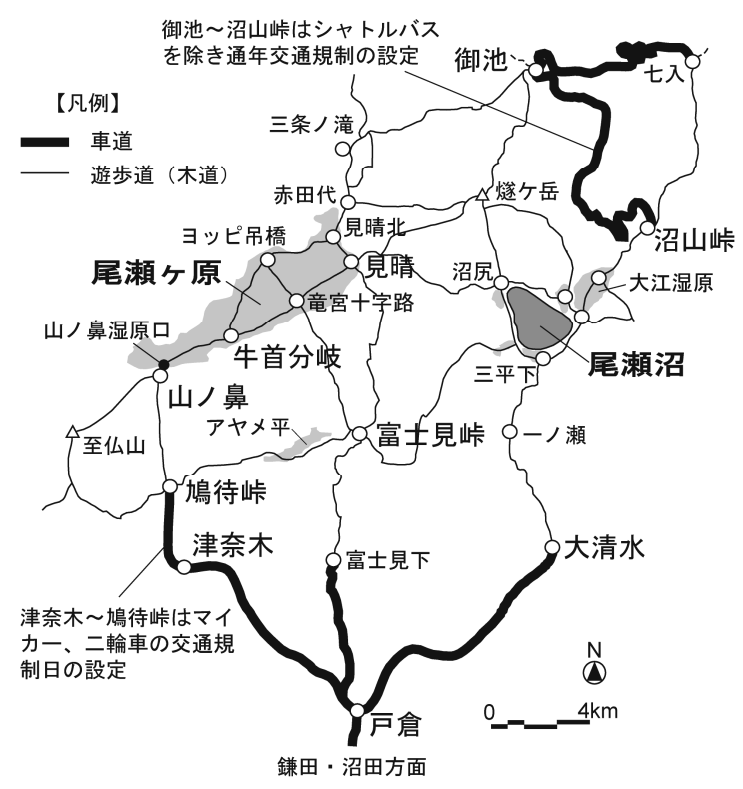

図－2 尾瀬国立公園 - 尾瀬ヶ原と尾瀬沼地区の概況図

表-1 山ノ鼻湿原口での湿原の出入り人数の計測概要

\begin{tabular}{|l|c|c|c|}
\hline \multicolumn{1}{|c|}{ シーズン } & 実施年月日 & 曜日 & 天気 \\
\hline ニッコウキスゲの開花期 & 2007 年 7月 28 日 7 15 時 & 土 & 晴 \\
\hline 紅葉期 & 2007 年 10月 月 日 7 15 時 & 土 & 晴 \\
\hline ミズハシショウの開花期 & 2009 年 6 月 6 日 7 15 時 & 土 & 晴 \\
\hline
\end{tabular}

調査員が数取り器を使い, 山ノ鼻方面から湿原に入る人数と, 湿 原から山ノ鼻に出る人数を同時にカウントした。この計測作業は, シーズン中で最も混雑するミズバショウとニッコウキスゲの開花 期，紅葉期の土曜日を対象にした（表一 1$)$ 。

カウント集計は, 当該日の 7 時から 15 時まで 7 分 30 秒単位で 行った。その理由は，混雑している尾瀬ヶ原において休唕の有無 に関係ない平均的な歩行速度は約 $1.1 \mathrm{~m} / \mathrm{s}^{8)}$ であり, 尾瀬ヶ原の木 道において見通せる範囲は約 $500 \mathrm{~m}^{10)}$ であるため，一般的に利用 者が約 $500 \mathrm{~m}$ を約 7 分 30 秒で移動する。したがって, 7 分 30 秒 単位のカウント集計による計測データは，可視約 $500 \mathrm{~m}$ 内の利用 状況を捉えるのに適当な単位であるからである。

（4）山ノ鼻〜牛首分岐中間部の単位時間別の利用状況の分析

利用状況の計測データをもとにして山ノ鼻〜牛首分岐中間部 の木道の利用状況を調べ, 既往研究データの混雑感の指標值と照 合し，混雑感を生じる時間帯とその大きさを明らかにした。

平均的な歩行速度は約 $1.1 \mathrm{~m} / \mathrm{s}$ であるので, 15 分間に約 $1 \mathrm{~km}$ 移 動する。山ノ鼻〜牛首分岐中間部の木道は，山ノ鼻から $1.1 \mathrm{~km}$ の 
表一2＼cjkstart尾瀬ヶ原における混雑感に係わる既往研究の一覧

\begin{tabular}{|c|c|c|c|c|}
\hline \multicolumn{2}{|r|}{ 研究論文 } & 研究概要 & 研究の成果 & 成果の集約 \\
\hline$A$ & 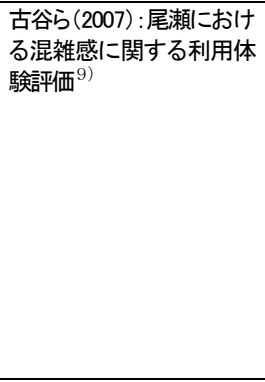 & 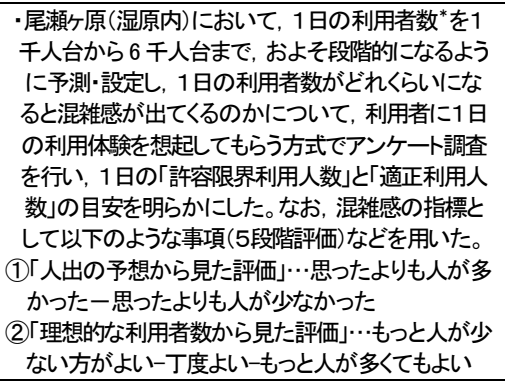 & 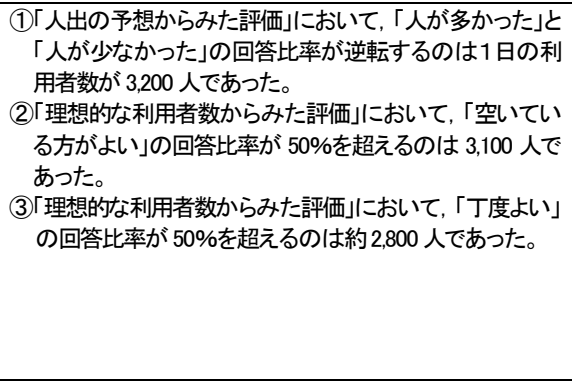 & $\begin{array}{l}\text {-(1)と(2)の結果を総合すると, } 1 \\
\text { 日の利用者数約 } 3,200 \text { 人が混 } \\
\text { 雑感をもたらさない「1日の許 } \\
\text { 容限界利用人数」になると推 } \\
\text { 定される。 } \\
\text {-(3)の結果から1日の利用者数 } \\
\text { 約 2,800 人以下が混雑感のな } \\
\text { い「1日の適正利用人数」にな } \\
\text { ると推定される。 }\end{array}$ \\
\hline$B$ & $\begin{array}{l}\text { 一場ら(2006) : 尾瀬ヶ原の } \\
\text { 休顋テラスから見た木道 } \\
\text { 上の混雑感評価 }{ }^{10)}\end{array}$ & $\begin{array}{l}\text { ·尾瀬ヶ原において, 休螅テラスから見た場合の木 } \\
\text { 道上の利用者数と混雑感評価との関係について, } \\
\text { (1)利用状況を段階区分した写真を用いた混雑感評 } \\
\text { 価, (2)リアルタイムな木道上の混雑感評価の結果 } \\
\text { を総合的に分析し, 混雑感評価の指標となる木道 } \\
\text { 上の利用者数を明らかにしした。 }\end{array}$ & $\begin{array}{l}\text { ·尾瀬ヶ原牛首分岐の休款テラスで, 可視 } 500 \mathrm{~m} \text { 内の木道上 } \\
\text { の利用状況を7分間以上眺めた場合の混雑感評価 } \\
\text { (1)利用密度感や満足感の許容限界(高いとも低いともどち } \\
\text { らとも言えないレべル)の利用者数は約 } 100 \text { 人であった。 } \\
\text { (2)利用密度は低いと感じ, 満足感の高い利用者数は約 } 20 \\
\text { ３0 人であった。 }\end{array}$ & $\begin{array}{l}\text { •回帰式による算出データの平 } \\
\text { 均值換算 } \\
\text { (1)(利用密度感 } 99 \text { 人十満足感 } \\
100 \text { 人) } \div 2 \Rightarrow 100 \text { 人(平均) } \\
\text { (2)(利用密度感 } 31 \text { 人十満足感 } \\
22 \text { 人) } \div 2 \Rightarrow 27 \text { 人(平均) }\end{array}$ \\
\hline \multirow[t]{2}{*}{$\mathrm{C}$} & \multirow[t]{2}{*}{$\begin{array}{l}\text { 田村ら(2003) : 尾瀬ヶ原の } \\
\text { 木道上における利用者間 } \\
\text { の距離と混雑感及び混雑 } \\
\text { 不快感との関係性 }^{11)}\end{array}$} & $\begin{array}{l}\text { ·尾瀬ヶ原において, 実際の歩行体験の中で混雑感 } \\
\text { 及び混雑不快感を受|ナた時の木道上の利用密度を } \\
\text { 分析し, (1)混雑を感じるが不快ではない, (2)混雑感 } \\
\text { による不快を感じる, (3)混雑を感しないといったタ } \\
\text { イプ別の利用者間の距離(間距)を明らかにした。 }\end{array}$ & $\begin{array}{l}\text { ·木道の歩行体験から見た利用者間の距離 } \\
\text { (1)混雑を感じるが不快ではない利用者間の距離は } 5.0 \mathrm{~m} / \text { 人 } \\
\text { であった。 } \\
\text { (2)混雑にこよる不快を感じる利用者間の距離は } 4.2 \mathrm{~m} / \text { 人であ } \\
\text { フた。 } \\
\text { (3)混雑を感じない利用者間の距離は } 9.2 \mathrm{~m} / \text { 人であった。 }\end{array}$ & $\begin{array}{l}\text { ·可視 } 500 \mathrm{~m} \text { 内の人数換算 } \\
\text { (1) } 500 \mathrm{~m} \div 5.0 \mathrm{~m} / \text { 人 } \Rightarrow 100 \text { 人 } \\
\text { (2) } 500 \mathrm{~m} \div 4.2 \mathrm{~m} / \text { 人 } \Rightarrow 119 \text { 人 } \\
\text { (3) } 500 \mathrm{~m} \div 9.2 \mathrm{~m} / \text { 人 } \Rightarrow 54 \text { 人 }\end{array}$ \\
\hline & & $\begin{array}{l}\text { ·尾瀬ヶ原において, 現地での木道歩行イメージと混 } \\
\text { 雑感との関係を分析し, 限界間距値と理想間距値に } \\
\text { ついて明らかにした。 }\end{array}$ & $\begin{array}{l}\text { ·木道の歩行イメ一ジから見た利用者間の距離 } \\
\text { (1)道の歩行の際に, 前を歩く人との距離が狭まって嫌な } \\
\text { 気持ちになる距離は } 4.0 \mathrm{~m} / \text { 人であった。 } \\
\text { (2)木道の歩行の際に, 前を歩く人との距離が気持ちの良い } \\
\text { と思う距離は } 12.0 \mathrm{~m} / \text { 人であつた。 }\end{array}$ & $\begin{array}{l}\text {-可視 } 500 \mathrm{~m} \text { 内の人数換算 } \\
\text { (1) } 500 \mathrm{~m} \div 4.0 \mathrm{~m} / \text { 人 } \Rightarrow 125 \text { 人 } \\
\text { (2) } 500 \mathrm{~m} \div 12.0 \mathrm{~m} / \text { 人 } \Rightarrow 42 \text { 人 }\end{array}$ \\
\hline
\end{tabular}

*ここでの1日当たりの利用者数とは, 湿原内の利用者数のことをいい, 山鼻でのカウンタ一値に加えて前日に湿原内の山小屋に宿泊している人数や御池側からの流入人数の推計值が含ま れている。

地点に当たるので，ほぼ 15 分間の歩行距離の地点と一致する。 したがって，山ノ鼻〜牛首分岐中間部の木道の往来状況は，山ノ 鼻から湿原に入る単位時間の人数だけを 15 分遅らせれば, ほぼ 重なる。以上のようなことから利用状況の計測データを加工して 用いた。

\section{（5）混雑感の改善策の考察}

(4)の分析結果を踏まえて山ノ鼻〜牛首分岐の木道における混 雑感をもたらす利用構造を明らかにし，その改善策メニューを整 理し，現実的な混雑感の改善策について提案した。

\section{3. 結果と考察}

\section{(1) 既往研究成果の抽出・整理}

山ノ鼻〜牛首分岐の木道の混雑感の改善策に利用できる既往 研究を抽出し，その成果を表一2のように整理した。

研究論文 $\mathrm{A}^{9)}$ の成果は, 尾瀬ヶ原における 1 日の利用体験の想 起に基づく混杂感データである。人出の予想からみた評価」にお いて，「人が多かった」と「人が少なかった」の回答比率が逆転す るのは 1 日の利用者数が 3,200 人であった。また，「理想的な利 用者数からみた評価」において，「空いている方がよい」の回答比 率が $50 \%$ を超えるのは 3,100 人であった。両者の結果を総合する と，尾瀬ヶ原において混雑感をもたらさない「1 日の許容限界利 用人数」は約 3,200 人になると考えられる。また，「理想的な利 用者数からみた評価」において，「丁度よい」の回答比率が $50 \%$ を超えるのは約 2,800 人であったことから，尾瀬ヶ原において混 雑感のない「1 日の適正利用人数」は約 2,800 人以下になると考 えられる。

研究論文 $\mathrm{B}^{10)}$ の成果は, 尾瀬ヶ原の牛首分岐の休憩テラスから 至仏山方向を見た木道上の利用状況を周囲の自然風景とともに客 観的に眺めた時の混雑感データである。牛首分岐の休憩テラスで, 可視 $500 \mathrm{~m}$ 内の木道上の利用状況を 7 分間以上眺めた場合, 利用 密度感や満足感の許容限界（高いとも低いともどちらとも言えな いレベル）の利用者数は約 100 人であった。つまり，可視 $500 \mathrm{~m}$
内の可視人数約 100 人が混杂感を感じない「許容限界利用人数」 になると考えられる。また, 利用密度は低いと感じ, 満足感の高 い利用者数は約 20〜30人であった。つまり，可視 $500 \mathrm{~m}$ 内の可 視人数約 $20 \sim 30$ 人が混杂隹感を感じない「適正利用人数」になる と考えられる。

研究論文 $\mathrm{C}^{11)}$ の成果は, 尾瀬ヶ原における木道の歩行体験から 見た利用者間の距離の置き方に関寸る混雑感データである。木道 の歩行体験から見た利用者間の距離については，混雑を感じるが 不快ではない利用者間の距離 $5.0 \mathrm{~m} /$ 人 (可視 $500 \mathrm{~m}$ 内の換算人数 100 人), 混雑による不快を感じる利用者間の距離 $4.2 \mathrm{~m} /$ 人 (同 119 人)，混雑を感じない利用者間の距離 $9.2 \mathrm{~m} /$ 人（同 54 人）で あった。また，現地での木道の歩行イメージから見た利用者間の 距離については，木道歩行の際に前を歩く人との距離が狭まって 嫌な気持ちになる距離 $4.0 \mathrm{~m} /$ 人 (可視 $500 \mathrm{~m}$ 内の換算人数 125 人), 木道歩行の際に前を歩く人との距離が気持ちの良いと思う距離 $12.0 \mathrm{~m} /$ 人（同 42 人）であった。

研究論文 B の成果は, 木道上の利用状況を外から見た客観的評 価であり, 研究論文 $\mathrm{C}$ の成果は利用体験からの実感的な評価であ る。本論では両者の成果を総合して，可視 $500 \mathrm{~m}$ 内の「許容限界 利用人数」（混雑は感じるものの不快までには感じずに許容でき る限界の利用人数）を 100 人とし，「適正利用人数」（混雑感のな い快適な利用人数）を $20 \sim 50$ 人として設定した（表一 3 )。特に 混雑感の改善にとって重要な指標は「許容限界利用人数」である。 その理由は，これを上回ると不快をもたらたす域に入るからであ る。研究論文 $\mathrm{C}$ の成果から可視 $500 \mathrm{~m}$ 内の「許容限界利用人数」 を上限值となる 119 人にすることも考えられるが，山ノ鼻〜牛首 分岐の区間は尾瀬ヶ原の中でも個性的で美しい区間になるので, 混雑感については㛜しく見ておく必要があるため 100 人とした。

（2）山ノ鼻～牛首分岐中間部の単位時間別の利用状況の分析

各計測日において，1 日（7～15 時）の湿原の出入り人数は, 表－4のようになった。山ノ鼻〜牛首分岐中間部まで行かずに途 中で引き返利用者もいると思われるが，およそこの人数が山ノ 
表-3 可視 $500 \mathrm{~m}$ 内の許容限界利用人数, 適正利用人数の設定

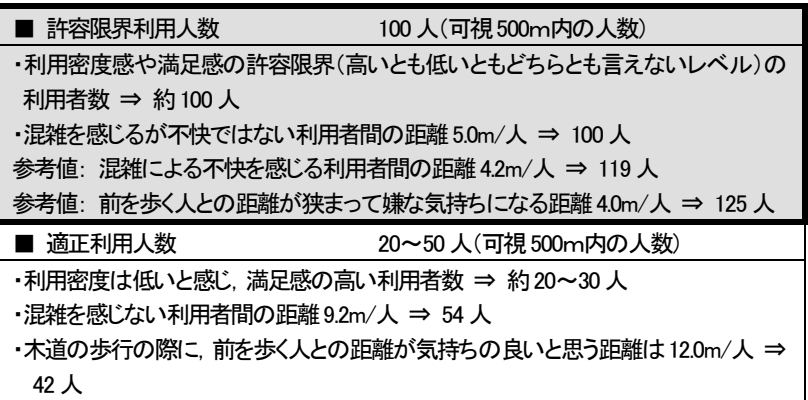

鼻〜牛首分岐中間部の木道を往来する人数になると見られる。

研究論文 $\mathrm{A}$ の成果である 1 日の利用者数（表一2）には，山ノ 鼻でのカウンター值に加えて前日に湿原内の山小屋に宿泊してい る人数や御池側からの流入人数の推計值が含まれている。したが って，表一 4 の利用者数とは一致するものではないので，両者を 比較できるように条件を合わせると，次のようになる。

湿原内の 10 軒の山小屋宿泊定員数は約 1,350 人である。各計 測日の平均宿泊率を計測データ A が 0.4 , 計測データ B が 0.5 ,

計測データ C が 0.7 とし ${ }^{16)}$, 宿泊者数を算出し, 御池からの流入 者数の推計值 100 人 ${ }^{17)}$ を加算すると, 表一 5 のようになる。この 推計值によれば，計測データAは「1 日の許容限界利用人数」約 3,200 人以内に収まる利用者数であり, 計測データ Bおよび C は それを超え，混雑感をもたらす利用者数であることがわかる。

加工した計測データによる山ノ鼻〜牛首分岐中間部の木道の 単位時間（7 分 30 秒）別の利用状況は，表一6〜8 のようになっ た。各表内の単位時間の合計は，木道上の往来者数になる。この 人数が「単位時間当たりの許容限界利用人数」 100 人を超える場 合に着色した。各表内の着色したセルの数は, 計測データ A が全 体 (61 セル) の $20 \%$ (12/61 セル), 計測データ B が 31\% (19/61 セル)，計測データ $\mathrm{C}$ が $61 \%$ (37/61 セル) であった。つまり， 計測データ A は 2 割が，計測データ $\mathrm{B}$ は 3 割が，計測データ $\mathrm{C}$ は 6 割が「単位時間当たりの許容限界利用人数」を超える結果に なった。

「単位時間当たりの許容限界利用人数」を超える時間帯は，計 測データ A では, 主に 10 時 30 分から 30 分間と 12 時 37 分から 約 40 分間であった。計測データ B では，主に 11 時 52 分から約 1 時間半のほとんどであった。計測データ $\mathrm{C}$ では，主に 9 時 22 分から約 1 時間 40 分と 12 時から約 2 時間半のほとんどであった。

（3）混雑感の改善策の考察

尾瀬ヶ原における混雑感に関寸る既往研究成果と特定混雑日 の山ノ鼻〜牛首分岐中間部の木道における実際の利用状況のデー タから次のような点が整理できる。

まず，「1 日の許容限界利用人数」約 3,200 人をもとにして各計 測データを照合すると, 計測データ A (推計 1 日約 3,000 人) は,

\section{表-4 計測日における湿原口の出入り人数（7～15 時）}

\begin{tabular}{|c|c|c|c|}
\hline \multicolumn{2}{|c|}{ 計測データ } & 山ノ鼻 $\Rightarrow$ 湿原 & 湿原 $\Rightarrow$ 山鼻 \\
\hline A & 2007 年7月 28 日(土) & 約 2,400 人 & 約 2,200 人 \\
\hline B & 2007 年 10 月 6 日(土) & 約 3,000 人 & 約 2,400 人 \\
\hline C & 2009 年 6 月 6 日(土) & 約 4,300 人 & 約 3,600 人 \\
\hline
\end{tabular}

\section{表一5 計測日における 1 日の尾瀬ヶ原の利用者数の推計}

\begin{tabular}{|c|c|c|c|}
\hline \multicolumn{2}{|c|}{ 計測データ } & $\begin{array}{c}\text { 1日当たりの尾瀬 } \\
\text { ケ原の利用者数 }\end{array}$ & $\begin{array}{c}\text { 湿原内の山小屋 } \\
\text { 宿泊者数と御池から } \\
\text { の流入人数の合計 }\end{array}$ \\
\hline A & 2007 年 7月 28 日(土) & 約 3,000人 & 約 640 人 \\
\hline B & 2007 年 10月 6 日(土) & 約 3,800人 & 約 780 人 \\
\hline C & 2009 年 6 月 6 日(土) & 約 5,400 人 & 約 1,050 人 \\
\hline
\end{tabular}

その範囲に収まり，計測データ B（推計 1 日約 3,800 人）と計測 データ C (推計 1 日約 5,400 人) は，その範囲に収まらない。つ まり，計測データ A は混䧱感をもたらすことはないが，計測デー タ $\mathrm{B}$ と C は混雑感をもたらすことになる。ただし，これは 1 日 の利用体験の想起に基づくものなので，実際に山ノ鼻〜牛首分岐 中間部の木道の単位時間 (7 分 30 秒) 別の利用状況について「単 位時間当たりの許容限界利用人数」 100 人をもとにして各計測デ 一タを照合すると，計測データ A は 2 割が，計測データ B は 3 割が，計測データ C は 6 割が，その人数を超えるものであった。

「単位時間当たりの許容限界利用人数」 100 人を超える場合, 理論的に湿原内に入る利用者数を調整し，混䧱感を改善しなけれ ばならない。例えば，許容限界利用人数をオーバーする時間帯を 調べて，その該当時間においては山ノ鼻の湿原口でその目安に収 まるようにオーバー分を非該当時間へシフトさせる必要がある。 しかし，この方法は計測データ A (表一6) のような利用状況で も $7 \sim 15$ 時まで単位時間の 2 割が連続的に混杂感をもたらす利用 状況であるので，実施にはやや難がある。ましてや計測データ B (表一7), 計測データ C (表-8）のような単位時間の 3 割, 6 割が連続的に混雑感をもたらす利用状況では実施がかなり難しい。

つまり，混雑感をもたらす該当時間が長く連続して続くと，利 用調整しなければならない人数が膨れあがり，これを非該当時間 ヘシフトさせることが難しくなるからである。そうなると湿原口 で多くの利用者が立ち往生することになり，特に滞在時間の短い 日帰り利用者は時間的に十分な利用ができないまま下山すること にもなろう。また，利用者の多くが現場に来てみないと十分に利 用できるかどうかわからない不確実な利用調整に対して敬遠し，

尾瀬に来訪しなくなる恐れもある。

このように尾瀬ヶ原において「1 日の許容限界利用人数」約 3,200 人を超える場合, 仮に計測データ $\mathrm{B}, \mathrm{C}$ のような利用パタ ーンになるとすれば，山ノ鼻〜牛首分岐の木道上で「単位時間当 たりの許容限界利用人数」 100 人を上回る混雑状況が連続的に発 生する可能性があり, 混雑しない時間帯への利用調整をすること は難しくなる。

したがって，山ノ鼻〜牛首分岐の木道において混雑感をもたら さないようにするためには，尾瀬ヶ原において 1 日約 3,200 人程 度（実際の利用データから厳しく評価すれば約 3,000 人程度）の 利用を基準とし，これを下回るように特に主要な入山口である鳩 待峠から尾瀬ヶ原に入る利用者数を何らかの方法で調整すること が重要な対策としてあげられる。近年の尾瀬ヶ原の利用動向では, 1 日約 3,200 人を超える日が入山シーズン約 150 日中 10 日前後 になると推測され ${ }^{18)}$ ，これを特定混雑日として対策をとればよい ことになる。そこで，仮に特定混雑日を「10日」とし，いずれの 日も計測データ B，Cのように単位時間が連続的に混雑感をもた らす利用パターンになるという想定のもとに対策を検討する。

加藤（2008）は，利用集中の問題について「『利用の分散』を 軸に検討し，一般的には，まず誘導的な対策を行い，その効果が 期待できない，あるいは種々の状況からその実施が不可能である 場合には規制的な対策を行い，それでも対応が難しい場合は，最 後の段階として利用者数の制限という対策に進むべきである」と 述べている ${ }^{19)}$ 。本論においても利用の平準化を図るという観点か ら利用の分散を軸にして誘導的な対策，規制的な対策（人数制限 を含む）という段階を踏まえて提案することにする。

本論での「利用の分散」とは，特定混雑日に鳩待峠から尾瀬ヶ 原を利用したいと考える利用者に対して，(1)他の自然公園などへ の利用変更, (2)特定混雑日以外の日への利用変更, (3)他の入山口 や登山ルートへの利用変更，などを想定するものである。こうし た利用分散行動を引き起こすインパクトを当該利用者に与えるこ とが対策になる。そこで，誘導的な対策と規制的な対策という枠 
組みで混雑感の改善策の試案を整理すると表一 9 のようになる。

対策 $\mathrm{A}-1$-1）は，各種の利用情報提供によって特定混雑日の鳩 待峠の利用集中緩和を図るものである。尾瀬保護財団は，2006 年から財団ホームページ内に「快適な尾瀨利用のススメ」という

\section{表一6 計測データ A・山ノ鼻〜牛首分岐中間部の利用者数}

(尾瀬ヶ原 1 日の推定利用者数約 3,000 人)

\begin{tabular}{|c|r|r|r||c|r|r|r|}
\hline 時刻 & IN & OUT & 合計 & 時刻 & \multicolumn{1}{|l|}{ IN } & OUT & 合計 \\
\hline $7: 00: 00$ & - & - & - & $11: 00: 00$ & 28 & 11 & 39 \\
\hline $7: 07: 30$ & - & - & - & $11: 07: 30$ & 39 & 30 & 69 \\
\hline $7: 15: 00$ & 12 & 1 & 13 & $11: 15: 00$ & 39 & 45 & 84 \\
\hline $7: 22: 30$ & 13 & 4 & 17 & $11: 22: 30$ & 36 & 31 & 67 \\
\hline $7: 30: 00$ & 21 & 6 & 27 & $11: 30: 00$ & 26 & 56 & 82 \\
\hline $7: 37: 30$ & 33 & 2 & 35 & $11: 37: 30$ & 45 & 33 & 78 \\
\hline $7: 45: 00$ & 13 & 0 & 13 & $11: 45: 00$ & 45 & 49 & 94 \\
\hline $7: 52: 30$ & 41 & 0 & 41 & $11: 52: 30$ & 48 & 37 & 85 \\
\hline $8: 00: 00$ & 21 & 5 & 26 & $12: 00: 00$ & 52 & 44 & 96 \\
\hline $8: 07: 30$ & 17 & 0 & 17 & $12: 07: 30$ & 55 & 50 & 105 \\
\hline $8: 15: 00$ & 10 & 8 & 18 & $12: 15: 00$ & 24 & 31 & 55 \\
\hline $8: 22: 30$ & 4 & 1 & 5 & $12: 22: 30$ & 40 & 33 & 73 \\
\hline $8: 30: 00$ & 26 & 0 & 26 & $12: 30: 00$ & 28 & 43 & 71 \\
\hline $8: 37: 30$ & 11 & 2 & 13 & $12: 37: 30$ & 68 & 52 & 120 \\
\hline $8: 45: 00$ & 26 & 3 & 29 & $12: 45: 00$ & 45 & 104 & 149 \\
\hline $8: 52: 30$ & 31 & 2 & 33 & $12: 52: 30$ & 43 & 130 & 173 \\
\hline $9: 00: 00$ & 37 & 10 & 47 & $13: 00: 00$ & 63 & 223 & 286 \\
\hline $9: 07: 30$ & 29 & 4 & 33 & $13: 07: 30$ & 25 & 134 & 159 \\
\hline $9: 15: 00$ & 17 & 1 & 18 & $13: 15: 00$ & 7 & 124 & 131 \\
\hline $9: 22: 30$ & 18 & 5 & 23 & $13: 22: 30$ & 43 & 50 & 93 \\
\hline $9: 30: 00$ & 29 & 19 & 48 & $13: 30: 00$ & 24 & 95 & 119 \\
\hline $9: 37: 30$ & 24 & 2 & 26 & $13: 37: 30$ & 26 & 69 & 95 \\
\hline $9: 45: 00$ & 14 & 5 & 19 & $13: 45: 00$ & 38 & 49 & 87 \\
\hline $9: 52: 30$ & 71 & 6 & 77 & $13: 52: 30$ & 8 & 11 & 19 \\
\hline $10: 00: 00$ & 9 & 31 & 40 & $14: 00: 00$ & 2 & 69 & 71 \\
\hline $10: 07: 30$ & 33 & 3 & 36 & $14: 07: 30$ & 25 & 40 & 65 \\
\hline $10: 15: 00$ & 30 & 37 & 67 & $14: 15: 00$ & 2 & 27 & 29 \\
\hline $10: 22: 30$ & 62 & 27 & 89 & $14: 22: 30$ & 30 & 15 & 45 \\
\hline $10: 30: 00$ & 114 & 48 & 162 & $14: 30: 00$ & 16 & 34 & 50 \\
\hline $10: 37: 30$ & 142 & 31 & 173 & $14: 37: 30$ & 5 & 17 & 22 \\
\hline $10: 45: 00$ & 124 & 15 & 139 & $14: 45: 00$ & 28 & 11 & 39 \\
\hline $10: 52: 30$ & 100 & 11 & 111 & $14: 52: 30$ & - & - & - \\
\hline
\end{tabular}

[凡例] IN …山鼻 $\Rightarrow$ 湿原 OUT $\cdots$ 湿原 $\Rightarrow$ 山鼻

\section{表一7 計測データB・山ノ鼻〜牛首分岐中間部の利用者数}

(尾瀬ヶ原 1 日の推定利用者数約 3,800 人)

\begin{tabular}{|c|r|r|r||c|r|r|r|}
\hline 時刻 & IN & OUT & 合計 & 時刻 & IN & OUT & \multicolumn{1}{|c|}{ 合計 } \\
\hline $7: 00: 00$ & - & - & - & $11: 00: 00$ & 33 & 45 & 78 \\
\hline $7: 07: 30$ & - & - & - & $11: 07: 30$ & 40 & 58 & 98 \\
\hline $7: 15: 00$ & 9 & 2 & 11 & $11: 15: 00$ & 51 & 19 & 70 \\
\hline $7: 22: 30$ & 29 & 0 & 29 & $11: 22: 30$ & 29 & 52 & 81 \\
\hline $7: 30: 00$ & 35 & 3 & 38 & $11: 30: 00$ & 62 & 72 & 134 \\
\hline $7: 37: 30$ & 33 & 1 & 34 & $11: 37: 30$ & 53 & 23 & 76 \\
\hline $7: 45: 00$ & 41 & 0 & 41 & $11: 45: 00$ & 44 & 26 & 70 \\
\hline $7: 52: 30$ & 38 & 7 & 45 & $11: 52: 30$ & 37 & 94 & 131 \\
\hline $8: 00: 00$ & 46 & 0 & 46 & $12: 00: 00$ & 25 & 50 & 75 \\
\hline $8: 07: 30$ & 46 & 4 & 50 & $12: 07: 30$ & 40 & 85 & 125 \\
\hline $8: 15: 00$ & 16 & 3 & 19 & $12: 15: 00$ & 87 & 43 & 130 \\
\hline $8: 22: 30$ & 33 & 2 & 35 & $12: 22: 30$ & 75 & 55 & 130 \\
\hline $8: 30: 00$ & 27 & 0 & 27 & $12: 30: 00$ & 40 & 68 & 108 \\
\hline $8: 37: 30$ & 28 & 0 & 28 & $12: 37: 30$ & 72 & 52 & 124 \\
\hline $8: 45: 00$ & 39 & 3 & 42 & $12: 45: 00$ & 24 & 59 & 83 \\
\hline $8: 52: 30$ & 50 & 4 & 54 & $12: 52: 30$ & 65 & 62 & 127 \\
\hline $9: 00: 00$ & 31 & 5 & 36 & $13: 00: 00$ & 51 & 85 & 136 \\
\hline $9: 07: 30$ & 26 & 7 & 33 & $13: 07: 30$ & 46 & 64 & 110 \\
\hline $9: 15: 00$ & 28 & 61 & 89 & $13: 15: 00$ & 58 & 146 & 204 \\
\hline $9: 22: 30$ & 99 & 0 & 99 & $13: 22: 30$ & 98 & 94 & 192 \\
\hline $9: 30: 00$ & 38 & 20 & 58 & $13: 30: 00$ & 58 & 48 & 106 \\
\hline $9: 37: 30$ & 40 & 5 & 45 & $13: 37: 30$ & 23 & 75 & 98 \\
\hline $9: 45: 00$ & 35 & 11 & 46 & $13: 45: 00$ & 17 & 57 & 74 \\
\hline $9: 52: 30$ & 21 & 27 & 48 & $13: 52: 30$ & 45 & 96 & 141 \\
\hline $10: 00: 00$ & 51 & 10 & 61 & $14: 00: 00$ & 13 & 72 & 85 \\
\hline $10: 07: 30$ & 57 & 53 & 110 & $14: 07: 30$ & 13 & 97 & 110 \\
\hline $10: 15: 00$ & 51 & 14 & 65 & $14: 15: 00$ & 23 & 42 & 65 \\
\hline $10: 22: 30$ & 54 & 21 & 75 & $14: 22: 30$ & 32 & 28 & 60 \\
\hline $10: 30: 00$ & 99 & 20 & 119 & $14: 30: 00$ & 51 & 67 & 118 \\
\hline $10: 37: 30$ & 55 & 26 & 81 & $14: 37: 30$ & 39 & 16 & 55 \\
\hline $10: 45: 00$ & 102 & 24 & 126 & $14: 45: 00$ & 76 & 11 & 87 \\
\hline $10: 52: 30$ & 38 & 22 & 60 & $14: 52: 30$ & - & - & - \\
\hline$[8$ & & & & & & & \\
\hline
\end{tabular}

[凡例] IN …山鼻 $\Rightarrow$ 湿原 OUT $\cdots$ 湿原 $\Rightarrow$ 山鼻
ページを設け，例えば，(1)特定混雑日の予報，(2)特定混雑日以外 の日の尾瀬ヶ原の利用情報（自然観察会の開催日時や人気のある 花の開花スポット）の提供，(3/他の低利用ルートやエリア（アヤ メ平・大清水・燧裏林道ルートなど）の見所紹介などを行い，利 用の分散を促進しようとしている ${ }^{20)}$ 。こうした利用情報の内容を さらに拡充し, 関連機関・団体のホームページへのリンクなど様々 な媒体を通じて利用者に身近に届くようにする必要がある。

対策 $\mathrm{A}-2$ ） は，特定混雑日と空いている日において施設や少 一ビスの利用料金に格差をつけて特定混雑日から空いている日に 利用を誘導し，これによって鳩待峠の利用集中緩和を図るもので ある。例えば, (1)尾瀬ヶ原内の山小屋宿泊料金，(2)戸倉の駐車場 利用料金，(3)尾瀬ヶ原での自然ガイド料金について，特定混雑日 は割増料金とし，空いている日は割引料金にする。つまり，空い ている日に料金を下げて, 数量を上げて営業利益をカバーすると いう方法があげられる ${ }^{21)}$ 。こうした方法で鳩待峠の利用集中緩和

\section{表一8 計測データC・山ノ鼻〜牛首分岐中間部の利用者数} (尾瀬ヶ原 1 日の推定利用者数約 5,400 人)

\begin{tabular}{|c|c|c|c|c|c|c|c|}
\hline 時刻 & IN & OUT & 合計 & 時刻 & IN & OUT & 合計 \\
\hline $7: 00: 00$ & - & - & - & $11: 00: 00$ & 116 & 54 & 170 \\
\hline $7: 07: 30$ & - & - & - & $11: 07: 30$ & 42 & 95 & 137 \\
\hline $7: 15: 00$ & 97 & 2 & 99 & $11: 15: 00$ & 43 & 51 & 94 \\
\hline $7: 22: 30$ & 71 & 2 & 73 & $11: 22: 30$ & 43 & 39 & 82 \\
\hline 7:30:00 & 57 & 1 & 58 & $11: 30: 00$ & 62 & 33 & 95 \\
\hline $7: 37: 30$ & 36 & 2 & 38 & $11: 37: 30$ & 41 & 63 & 104 \\
\hline $7: 45: 00$ & 75 & 1 & 76 & $11: 45: 00$ & 67 & 27 & 94 \\
\hline $7: 52: 30$ & 58 & 1 & 59 & $11: 52: 30$ & 32 & 48 & 80 \\
\hline 8:00:00 & 53 & 4 & 57 & 12:00:00 & 89 & 75 & 164 \\
\hline $8: 07: 30$ & 49 & 10 & 59 & $12: 07: 30$ & 76 & 46 & 122 \\
\hline $8: 15: 00$ & 39 & 19 & 58 & $12: 15: 00$ & 56 & 76 & 132 \\
\hline $8: 22: 30$ & 31 & 15 & 46 & $12: 22: 30$ & 67 & 80 & 147 \\
\hline $8: 30: 00$ & 48 & 46 & 94 & $12: 30: 00$ & 97 & 121 & 218 \\
\hline $8: 37: 30$ & 85 & 33 & 118 & $12: 37: 30$ & 48 & 95 & 143 \\
\hline $8: 45: 00$ & 53 & 16 & 69 & $12: 45: 00$ & 80 & 89 & 169 \\
\hline $8: 52: 30$ & 50 & 27 & 77 & $12: 52: 30$ & 80 & 85 & 165 \\
\hline 9:00:00 & 106 & 26 & 132 & $13: 00: 00$ & 59 & 117 & 176 \\
\hline 9:07:30 & 37 & 14 & 51 & $13: 07: 30$ & 76 & 91 & 167 \\
\hline 9:15:00 & 28 & 12 & 40 & $13: 15: 00$ & 45 & 89 & 134 \\
\hline $9: 22: 30$ & 122 & 31 & 153 & $13: 22: 30$ & 116 & 134 & 250 \\
\hline $9: 30: 00$ & 102 & 38 & 140 & $13: 30: 00$ & 55 & 116 & 171 \\
\hline $9: 37: 30$ & 101 & 49 & 150 & $13: 37: 30$ & 93 & 128 & 221 \\
\hline $9: 45: 00$ & 106 & 28 & 134 & $13: 45: 00$ & 118 & 124 & 242 \\
\hline $9: 52: 30$ & 92 & 57 & 149 & $13: 52: 30$ & 64 & 157 & 221 \\
\hline $10: 00: 00$ & 40 & 94 & 134 & $14: 00: 00$ & 81 & 157 & 238 \\
\hline $10: 07: 30$ & 69 & 26 & 95 & $14: 07: 30$ & 62 & 70 & 132 \\
\hline $10: 15: 00$ & 76 & 49 & 125 & $14: 15: 00$ & 78 & 149 & 227 \\
\hline $10: 22: 30$ & 82 & 61 & 143 & $14: 22: 30$ & 59 & 129 & 188 \\
\hline $10: 30: 00$ & 80 & 40 & 120 & $14: 30: 00$ & 22 & 65 & 87 \\
\hline $10: 37: 30$ & 28 & 75 & 103 & $14: 37: 30$ & 16 & 101 & 117 \\
\hline $10: 45: 00$ & 66 & 27 & 93 & $14: 45: 00$ & 22 & 41 & 63 \\
\hline $10: 52: 30$ & 91 & 62 & 153 & $14: 52: 30$ & - & - & - \\
\hline
\end{tabular}

表－9 尾瀬ヶ原 1 日約 3,200 人以下の利用にする対策試案一覧

\begin{tabular}{|c|c|c|}
\hline \multicolumn{2}{|c|}{ 対 策 } & 具 体 例 \\
\hline \multirow{11}{*}{$\begin{array}{l}\text { A } \\
\text { 誘 } \\
\text { 導 } \\
\text { 的 } \\
\text { 対 } \\
\text { 策 }\end{array}$} & 1)利用情報提供 & ·特定混雑日の予報 \\
\hline & & ·特定混雑日以外の日の尾瀬ヶ原の楽しみ方の情報提 \\
\hline & & 供（自然観察会などの開催日時, 人気のある花の開 \\
\hline & & 花スポツトなど） \\
\hline & & ·他の低利用ル一トやエリア(アヤメ平·大清水・燧裏林 \\
\hline & & 道ル一トなど)の情報提供 \\
\hline & 2)施設やサービ & ·特定混雑日の割増料金と空いている日の割引料金の \\
\hline & スの利用料金 & 設定 \\
\hline & の割増や割引 & (1)尾瀬ヶ原内の山小屋宿泊料金 \\
\hline & & (2)戸倉の駐車場利用料金 \\
\hline & & (3)尾瀬ヶ原での自然ガイド料金 \\
\hline \multirow{6}{*}{$\begin{array}{l}B \\
\text { 規 } \\
\text { 制 } \\
\text { 的 } \\
\text { 対 } \\
\text { 策 }\end{array}$} & 1)入山口までの & ·特定混雑日での鳩待峠から津奈木への入山口の引き \\
\hline & 交通アクセス & 下げ(入山口の遠隔化による交通アクセス制限) \\
\hline & の制限や緩和 & •特定混雑日での大清水 ～一瀬 富士見下 富士見峠 \\
\hline & & までの電気バス等の秉 \\
\hline & 2)完全予約制 & •特定混雑日での鳩待拤利用のみの完全予約制の実施 \\
\hline & & (尾瀬ヶ原の利用調整地区制度の適用による \\
\hline
\end{tabular}


を図ることは今までほとんど行われてこなかった。これについて は，マーケティング調査を行い，どれだけの利用集中緩和効果が 想定され，また事業者にとって経営的にプラスやマイナスになる のかを明確にし, 事業者の協力が得られるようにする必要がある。 対策 B-1) は, 特定混雑日において鳩待峠までの交通アクセス を制限し，一方，大清水以奥や富士見峠までの交通アクセスを緩 和し, 鳩待峠の利用集中緩和を図るものである。1974 年より片品 村尾瀬交通対策連絡協議会のもとで津奈木〜鳩待峠においてマイ カー及び二輪車の交通規制を行い，戸倉〜鳩待峠は乗合バス・乗 合タクシーの利用になった。しかしこれは，現状に見られるとお り鳩待峠の利用集中緩和にはつながらなかった。そこで，一つに は特定混雑日において，これまでの入山口を鳩待峠から津奈木ま で引き下げて，鳩待峠までの $3.5 \mathrm{~km}$ ，約 1 時間 30 分を歩くこと を検討する（入山口の遠隔化による交通アクセス制限）22）もう 一つは特定混雑日において，大清水〜一ノ瀬，富士見下〜富士見 峠での電気バス等の乗り入れによって両方の入山口アクセスの利 便性を高めることを検討する（交通アクセスの緩和） ${ }^{23)}$ 。入山口 の遠隔化による交通アクセス制限については，効果が出すぎて利 用者数が激减し，地域経済にダメージを与える可能性もある。ま ずはマーケティング調査とモニター調査を実施し, その効果を予 測・評価し，利用者や尾瀬関係者，地域住民，旅行会社などの意 見を十分に把握しながら検討する必要がある。

対策 B-2) は，尾瀬ヶ原に利用調整地区制度を適用し，特定混 雑日となる 10 日を鳩待峠のみ完全予約制とし，鳩待峠の利用集 中緩和を図るものである。これは，公園管理者が利用者から来訪 希望日を聞き，尾瀬ヶ原において 1 日 3,200 人以下の利用にする 予約手続きを行い,利用者から事務手数料を徵収することになる。 2011 年より利用調整地区制度を適用する知床五湖では, ヒグマ活 動期となる 5〜 7月の 82 日間は団体利用を基本とし事前予約制を とり, 立ち入り認定料として大人 500 円を徵収する予定である。 なお，この立ち入り認定料については，利用者数を予測し，スタ ッフの配置計画を行い, 運用コストを試算し, 必要経費に見合う ように設定している ${ }^{24)}$ 。尾瀬ヶ原においても，まず特定混雑日に 利用調整地区制度が適用可能であるのかどうかを検討し，その上 で知床五湖と同じような事務手続きについて検討寸る必要がある。

\section{4. まとめと今後の課題}

本論は，尾瀬ヶ原の山ノ鼻〜牛首分岐の木道における利用集中 による混雑感の問題を取り上げて, 既往の混雑感に関する知見と 実際の利用データをもとにして,その実態を明らかにした。また， その実態を踏まえて, 山ノ鼻〜牛首分岐の木道における混雑感を 改善するには, 尾瀬ヶ原において 1 日約 3,200 人程度の利用を基 準とし，これを下回るように，特に主要な入山口である鳩待峠か ら尾瀬ヶ原に入る利用者数を調整することが重要な対策になるこ とを示した。さらに，誘導的な対策と規制的な対策という枠組み で混雑感の改善策の試案とその適用上の課題について整理した。

本論で取り上げた混雑感の改善策の試案については，今後，適 用上の課題を解決した上で，各対策を組み合わせながら試行し， その中から最も適当かつ効果の高い対策を見出していく必要があ る。

今後の課題については, 本論では特定混雑日とそれに近い日の 利用パターン 3 例だけを取り上げて検討したものであるので，多 数の特定混雑日の利用パターンを調査し, 確実な実態把握を行う 必要がある。また，尾瀬ヶ原の山ノ鼻〜牛首分岐の一区間に限定 したものではなく，尾瀬ヶ原全体，さらに尾瀬沼や森林帯内の歩 道なども含め, 尾瀬内に数日滞在した場合の広域での混雑感の改 善策の検討なども必要である。
謝辞 本論は，尾瀬国立公園における利用体験上の収容力に関寸る一連の調査研究成 果を土台にしたものです。末尾ながら関係各位に謝意を表します。また，本論をサポ 一トしていただいた掘内佳菜氏，宮澤日奈子氏，吉野美沙樹氏にも謝意を表します。

\section{補注及び引用文献}

1）日下部甲太郎（1965）: 尾瀬をいかに守るか〜利用増に対応する計画〜：国立公園 193, 2-9

2）小林昭裕・愛甲哲也（2008）：適正収容力の概念と計画手法：小林昭裕・愛甲哲也 編『利用者の行動と体験』: 古今書院, 186-188

3)加藤峰夫 (2008) : アメリカの国立公園における「利用者数の調整」の具体例 : 加 藤峰夫『国立公園の法と制度』: 古今書院，225-227

4) 環境省近畿地方環境事務所 (2007) : 吉野熊野国立公園西大台地区利用適正化計画 : 近畿地方環境事務所, 12

5）吉野熊野国立公園西大台地区利用適正化計画検討協議会（2010）：平成 21 年度吉 野熊野国立公園西大台利用調整地区のモニタリング評価 : 近畿地方環境事務所, 4

6 ) 環境省釧路自然環境事務所・知床五湖の利用のあり方協議会 (2010) : 知床五湖利 用調整地区 利用適正化計画案（再々修正案）：釧路自然環境事務所他，9

7 ）尾瀬保護財団（2005）：利用体験から見た尾瀬の収容力に関する総合調査報告書： 尾瀨保護財団, $172 \mathrm{pp}$

$8 ）$ 一場博幸・中島敏博・古谷勝則（2005）：日光国立公園尾瀬ヶ原の木道における歩 行速度についての一考察 : ランドスケープ研究 68(5), 717-722

9）古谷勝則・一場博幸・中島敏博・望月宽・山崎人詩・麻生恵（2007）: 尾瀬におけ る混雑感に関する利用体験評価 : ランドスケープ研究 71(1), 47-54

10）一場博幸・下嶋聖・古谷勝則・麻生恵 (2006)：尾瀬ヶ原の休憩テラスから見た木 道上の混杂感評価に関寸る研究 : ランドスケープ研究 69 (5), 737-740

11）田村裕希・望月寛・麻生恵(2003) : 尾瀬ヶ原の木道上における利用者間の距離と 混雑感及び混雑不快感との関係性 : ランドスケープ研究 66 (5), 705-710

12 尾瀬保護財団の「尾瀬の保護と利用のあり方検討会」(2006) : 尾瀬ビジョン - 21 世紀の新しい国立公園にふさわしい，保護・利用・管理運営のあり方とその具体 化に向けて : 尾瀬保護財団, $20 \mathrm{pp}$

13) Shelby, B. and Heberlein, T. A (1986) :Carrying Capacity in Recreation Settings., Oregon State University Press, 164pp

14）愛甲哲也・浅川昭一郎（2000）: 混雑とマナ一の悪さに対寸る登山者の許容限界と コーピング行動について : ランドスケープ研究 63(5), 619-624

15）尾瀬保護財団（2010）：尾瀬の入山者数推移 : 尾瀬保護財団ホームページ $\langle\mathrm{http}: / /$ www. oze-fnd. or. jp/〉, 2010.9.10参照

16）尾瀬ヶ原内の山小屋への宿泊率のヒアリング $(2003$ ・2008 年) による推計

17）8）の 109 ページに記載された「御池から烇裏林道経由で尾瀬ヶ原に入る推定人数 は御池センサーの $40 \%$ を参考にして推定した。

18）尾瀬保護財団（2009）：尾瀬国立公園における利用集中に伴う影響調查報告書 : 尾 瀬保護財団, 215pp の入山者数データから推計した。

19)加藤峰夫 (2008) : アメリカの国立公園における「利用者数の調整」の具体例 : 加 藤峰夫『国立公園の法と制度』: 古今書院，220

20)一場博幸 (2007) : 尾瀬における適正利用へのアプローチ : 国立公園 658，16-19

21)その他, 戸倉〜鳩待峠のシャトルバス等の乗車運賃の割増や割引によって鳩待峠の 利用集中緩和を図る案は, 道路運送法第 9 条（運賃は適正な原価に適正な利潤を加 えたものを超えない)の問題があるために適用が難しい。また，特定混䧱日に鳩待 峠において特別に入園料的なものを徵収し，鳩街㱑の利用集中緩和を図る案は，自 然公園法や地権者との合意形成などの複杂隹な問題があるため, 本論では除外した。

22）菊地慶四郎 (2004) : 尾瀬アヤメ平の 40 年：上毛新聞社出版局, 111. 津奈木から 九鳥待峠まで利用者を歩かせて, 利用調整することを提案している。

23）上毛新聞社 (2009) : 車两規制の緩和検討・片品の 2 ルート・鳩待拤・入山者集中 で・尾瀬サミット:上毛新聞社ホームページ, 〈http://www. rai jin. com/oze / ki ji/ 090804. htm〉, 2009. 8.4 参照. 鳩待峠に入山者が集中している問題で, 片品村長が, 車両が原則通行禁止になっている別の村内の 2 つのルート（大清水〜一瀬，富 士見下〜富士見峠）の規制緩和を要望した。

24) 知床五湖の利用のあり方協議会 (2010) : 知床五湖利用調整地区立入認定料の試算 について: 知床五湖の利用のあり方協議会, $11 \mathrm{pp}$ 